\title{
Influence of Supplier Prequalification Criteria on Procurement Performance at Kenya Rural Roads Authority in the County Government of Nyamira
}

\author{
Kenneth Mwangi Mbuchi*, \& Dr. Josphat Kwasira \\ The Corresponding Author is a Master of Science in Procurement and Logistics student at Jomo Kenyatta \\ University of Agriculture and Technology, Nakuru Campus, Kenya. \\ Dr. Josphat Kwasira is a senior lecturer at Jomo Kenyatta University of Agriculture and Technology, Nakuru \\ Campus, Kenya. \\ Jomo Kenyatta University of Agriculture and Technology P.O Box 62000-00200, Nakuru
}

\begin{abstract}
Prequalification of suppliers is a critical stage in the procurement process because it helps an organization to identify potential supplier who could be called upon to provide goods and services. If not well done, the procuring entity would result in having to contract the wrong individuals or companies to supply goods services and works. It is also costly to have every procurement assignment to go through the entire process of advertisement and evaluation of suppliers. Working with a leaner group of suppliers would be both time saving and cost effective. All public procuring entities undertake supplier prequalification every year or every two years as per the public procurement and asset disposal act, however, it is not known how this impacts on performance of the procurement function. Kenya rural Roads Authority is a public institution that is highly dependent on contractors to execute its functions therefore its success is dependent on its ability to engage the right suppliers. The general objective of the study is to assess the influence of supplier prequalification on procurement performance at KeRRA, Nyamira County. The independent variables of the study include youth and women involvement, community participation, technical competencies, and contractual capacity. On the other hand, the dependent variable was the performance of procurement at KeRRA. The study utilized the agency theory and resource dependency theory. The study was done at KeRRA, Nyamira County using the descriptive research design. The target population was the staff of procurement department of KeRRA as well as the county government who collaborates in various projects. The target population was 114 from which a sample of 89 was selected using the stratified random sampling technique. The study used questionnaire as the main tool for collection of primary data. The data collection instrument was subjected to a pilot study in selected procurement staff in the neighbouring Kisii County. The study found that there was statistical significance between contractual capacity and procurement performance. The study also found a statistical significance between Youth, Women and Persons with Disabilities involvement in procurement activities and performance procurement. The study found a statistical significant relationship between technical capacity and procurement performance. Similarly, the study found a statistical significant relationship between community support and procurement performance. The multiple correlation effect of 0.538 indicates a relatively strong positive relationship effect between the four independent variables (Community Support, Contractual Capacity, Technical Capacity, Youth and Women Involvement) and the dependent variable (procurement performance). The coefficient of determination ( $R$ Square) indicates the variance on the dependent variable attributed to the four independent variables. In this context, the coefficient of determination ( $R$ Square) of 0.290 indicates that the four independent variables contributed to $29.0 \%$ of the variance in dependent variable. The study recommends that the procurement functions at KeRRA should pay closer attention to the contractual capacity as well as the Youth, women and PAD participation in the procurement as they had significant influence on procurement performance
\end{abstract}

Keywords: Contractual Capacity, Community Support, Technical Competency, Procurement Performance

\section{Introduction}

In Kenya, the government does not use state-owned enterprises to manufacture goods and services that public authorities require to perform their duties. Therefore the government has to purchase various goods and services from the supply market. This purchasing process is regulated by the Public Procurement and Disposal Act (PPDA) (2005) that provide for the conclusion of contracts between public entities and the providers of goods, works and services. The act also sets out required standards and procedures, while oversight transparency and accountability mechanisms are provided by the Public Procurement Oversight Authority (PPOA) (2007). Public procuring entities as established in the act include the Government or any department of the Government, the courts, commissions established under the Constitution, a local authority under the local government, state 
corporations, the Central Bank of Kenya, co-operative society, a public school, a public university or an entity prescribed as a public entity.

An assessment of the Procurement System in Kenya by the PPOA (2007) revealed that Public Procurement and Disposal Act (PPDA) 2007 and the Regulations established procuring entities were allowed to apply pre-qualification procedure from which quotations were raised for potential supplier in procurement contracts. Procuring Entities (PEs) were however required ensure a "fair and equal rotation" of supplier. However, the concept of "fair and equal rotation" was not adequately explained and illustrated, and may therefore result in misinterpretation among the PEs. Further, the report revealed that the procuring entity has a mandate to register contractors and maintaining registers categorizing these depending on capacity and qualifications. Further neither the PPDA nor the Regulations elaborates on evaluating the technical capacity of suppliers and contractors. The lack of clear procedures causes some confusion as to when and how to apply technical capacity as a key criterion in prequalification and selection of suppliers.

There has been also excessive use of quotations rated at $89.2 \%$ of all public procurement contracts as opposed to $1.3 \%$ open tenders. There have been also significant differences in PE procurement practices as well as lack of mechanism providing structured incentives for sound and efficient procurement among the system's key players (PPOA, 2007). Kenya as a country has been investing heavily on improvement of roads network owing to its critical role it plays in the economic development. In the financial year 2015/16 the government budgeted for KSh 58.5 billion for on-going road construction, KSh 26.7 billion for road maintenance, KSh 42.0 billion for foreign financed roads; and KSh 5.0 billion for the Road Annuity Programme. This implies that the government plans to spend 131.7 billion shilling on road projects solely implemented by the KeRRA, the Kenya National Highways Authority (KENHA) and the Kenya Urban Roads Authority (KURA). All these projects are to be implemented by firms contracted by these three firms.

The Kenya Rural Roads Authority (KeRRA), a State Corporation under the Ministry of Transport and Infrastructure was established under the Kenya Roads Act, 2007 and charged with the mandate to manage, develop, rehabilitate and maintain rural roads. The role of KeRRA under the vision 2030 is to provide cost effective world-class infrastructure facilities and services. This is achieved by strengthening the existing framework and accelerating the speed of implementation of rural roads projects while raising efficiency and quality. KeRRA implements roads construction by contracting qualified contractors to undertake the exercises. The mandate of KeRRA is to ensure that they procure the right services manage the contracts and ensure value for money in rural roads construction. This can therefore be achieved by ensuring that KeRRA has the right contractors assigned to construct roads.

The passing of the new constitution in Kenya in 2010 ushered in new order of promoting the youth and disadvantaged groups into empowering them economically. One of the strategies that the government put into place was to create a favorable playground into the tendering of government funded projects. This has created room for the said groups to be greatly involved in tendering of road construction around the counties. The significant role played by the supplier selection in the procurement process has forced the government to come up with stringent guidelines and specific criteria for their involvement. Although the guidelines are well explained and even displayed in public offices, still the prequalification criteria still has not been adhered to. KeRRA is a government institution charged with the construction of roads in the rural areas in Kenya using the contractor model.

Being a public entity, KeRRA is bound by the public procurement laws of Kenya which require public institutions to prequalify suppliers and contractors of services periodically and ensure fair award of contracts. However, previous evaluation reports have indicated weaknesses in the prequalification processes that affect the outcome of the procurement process such as the technical capacity of contractors, the selection criteria applied and the competency of the contractors (PPOA, 2007). There is however scanty empirical research examining the performance effects of supplier prequalification (Petersen, Handfield \& Ragatz, 2005). This study therefore seeks to assess the influence of supplier prequalification on procurement performance at the KeRRA Nyamira County.

\section{Theoretical Review}

\section{Literature Review}

The study was guided by the agency theory and Resource Dependency Theory of the Firm. Agency theory is concerned with agency relationships. The two parties have an agency relationship when they cooperate and engage in an association wherein one party (the principal) delegates decisions and/or work to another (an agent) to act on its behalf (Eisenhardt, 2009). The important assumptions underlying agency theory is that; potential goal conflicts exist between principals and agents; each party acts in its own self-interest; information asymmetry frequently exists between principals and agents; agents are more risk averse than the principal; and efficiency is the effectiveness criterion. Two potential problems stemming from these assumptions may arise in agency relationships: an agency problem and a risk-sharing problem (Fathi, 2013). 
An agency problem appears when agents' goals differ from the principals' and it is difficult or expensive to verify whether agents have appropriately performed the delegated work (i.e. moral hazard) (Makokha, 2013). This problem also arises when it is difficult or expensive to verify that agents have the expertise to perform the delegated work (i.e. adverse selection) that they claim to have. A risk-sharing problem arises when principals and agents have different attitudes towards risk that cause disagreements about actions to be taken (Xingxing, 2012). The assumptions and prescriptions of agency theory fit naturally with the issues inherent in supply chain quality management. In the process of managing supplier quality, buyers in agency relations are faced with potential problems.

By their nature, buyers expect suppliers to provide good quality and to improve the quality of supplied products and/or services, but suppliers may be reluctant to invest substantially in quality, especially if they perceive that buyers are reaping all the benefits. The difference between buyers and suppliers will result in the two parties concerning themselves only with their self-interests (Githemo, 2012).Agency theory determines how procurement managers execute procurement practices on behalf of KeRRA. Existence of poor principle agent relationship leads to low level of top management commitment and this also affects the relationship between institutions and the suppliers (Kariuki, 2013).Existence of conflict of interest amongst the agents leads to execution of procurement practices against the procurement the procurement policies and this leads to increased procurement budget and loss of procurement funds. The study thus will use this model to determine the procurement efficiency attributable to the prequalification exercise in KeRRA.

The Resource Dependency Theory (RDT) was originally developed by Pfeffer and Salancik (1978) based on the idea that resources are key to organizational success and that access and control over resources is a basis of power. Resources are often controlled by organizations not in the control of the organization needing them, meaning that strategies must be carefully considered in order to maintain open access to resources. The RDT shows how firms and other organizations rely on each other's resources in access to raw materials, goods, services, finance, knowledge among others for their survival and success. It is assumed, then, that buyers and suppliers are linked in a network through resource dependency and that these linkages or relationships are characterized by the exchange of existing resources and the creation of new resources. The theory draws from social exchange theory to examine how buyer-supplier relationships operate and evolve over time, using concepts such as expectations, co-operation, trust, commitment, communication and conflict behavior. Actors are assumed to be self-interested rather than opportunistic, and to recognize that serving their self-interest requires them to interact with others in a network context.

One of the key insights offered is that a single buyer supplier relationship can be characterized by both competitive and co-operative behavior, either simultaneously on different levels within each organization or at different times in the relationship. Firms are seen as organic and adaptive rather than mechanistic and rational (Davis \& Cobb, 2009). Suppliers are key resources in any organization since competent suppliers enable it effectively discharge their duties. The strength of organizations supplier base is determined at the prequalification stage in which supplier identify that supplier with capability to meet organizational goals effectively. This theory would therefore be used to explain how the supplier base of KeRRA contributes to effectiveness in the execution of its duties.

\section{Contractual Capacity and Procurement Performance}

The contacts created through procurement of goods and services must be enforceable in order for each party to secure their rights. There are often costs associated with the creation of enforceable contracts (Mungai, 2014). The contracting costs include the cost of negotiation as well as legal and administrative costs incurred in the creation of enforceable contract to satisfy both trading parties. This implies that both parties must have the capacity and expertise (contractual capacity) to meet these diverse needs and requirements (Simbiri, 2010).The need for each of the trading parties to have the contractual capacity is informed on the fact that the infrastructural projects involve large financial resources and there is always the threat of costly litigation if any of the parties is not satisfied with the execution of the contract (Mwangi, 2014). The contractual capacity is therefore important in procurement performance by ensuring that each institution adheres to its part of responsibilities in terms of the scope of work, quality of work, timelines of project execution, and budget allocation (Simbiri, 2010).

The nature of the public infrastructure procurement involves relatively large amounts of budget considerations as well the complexity of the scope of work involved (Mungai, 2014). This is especially so in terms of the road construction in which by nature is a complicated task involving heavy machinery, technical skills and the financial resources (Amin, 2012). The ability of the firm tendering to undertake a given piece of work to have undertaken similar projects in the past is of critical importance to the performance of public procurement in infrastructural projects (Chirchir, 2013). This is because the past experiences indicate that the firms from which the services are being procured from have expertise to undertake the scope of work and have embraced the best practices that go with the work under scope. 
This ability to embrace the best practices over a period of time enhances the procurement performance as the firm saves on time and undertakes quality work (Kulundu, 2014). The aspect of time management is a critical performance measurement on the procurement performance within road infrastructure improvement and development. Firms lacking past experiences in undertaking a given scope of work are likely to underestimate the complexity of the work and the required time as well as resources requirements (Mauki, 2014).

In adequate time management within road construction is likely to lead to cost escalations beyond the projected and budgeted for costs due to changing dynamics such as change of weather into rainy seasons and well as the budgetary cycle within the government (Ngotho, 2014). On the other hand, the firms without the required past experiences are likely to under estimate the financial resources required to undertake a given scope of work (Odongo, 2012). This impact greatly on the procurement performance when are not able to complete the work within the budget allocations. The firms are likely to request for more budget allocation to meet the raising costs or undertake a poor performance of the work with the required resources (Mbae, 2014). Either way the procuring entity doesn't get the value for money.

The value of work undertaken in the past is important to the contractual capacity of a given firm. The examination of the value of work undertaken in the past helps the procuring entity to determine on whether the firm had the enough capacity and expertise in terms of the number of employees, the skills set of the employees, and the required equipment (Mungai, 2014). If the value of the work undertaken is significantly lower than the current project then it may mean that the company may not have the capacity to undertake the current work (Ngunyi, 2014).

\section{Youth, Women and People with Disabilities Involvement in Procurement}

There are several provisions within the Public Procurement and Disposal act 2013 that protects the rights of the youth, women and people with disabilities to participate in procurement (Muange, 2013). The Public Procurement and Disposal Act of 2013 indicate that each public procuring entity must allocate at least $30 \%$ of its procurement within the financial year to the youth, women and people with disability (Mauki, 2014). The Public Procurement and Disposal Act of 2013 made amendments to section 3 of act number 3 of 2005 in order to define the youth within the meaning of the act. The youth was taken to mean people within the age of 18-35 years including a company, association or body of persons, corporate or unincorporated in which all its directors or proprietors are persons who are within the age of 18-35 (Mungai, 2014). The procuring entities are not supposed to pose any unnecessary impediment to the youth participating in public procurement.

The Public Procurement and Disposal Act of 2013 also limited the right of equality and freedom within the meaning of this act in order to remove any legal impediments on application of $30 \%$ special allocation to youth and women (Muange, 2013). This was undertaken with a view of facilitating the affirmative action to ensure the youth access employment and have opportunities to participate in economic spheres of life as contemplated by Article 55 of the Constitution and second, for protection or advancement of the youth in accordance with Article 227 of the Constitution who have previously been disadvantaged by unfair competition and discrimination in the procurement process (Ngotho, 2014).

For an enterprise to benefiting from preference and reservations schemes, the enterprise should be a legal entity that: Is registered with the relevant government body and has at least seventy percent membership of youth, women or persons with disabilities and the leadership shall be one hundred percent youth, women and persons with disability (Kulundu, 2014). The required documents of an enterprise include: Identity Card(s)/Passport(s), Business Registration Certificate/ Certificate of Incorporation, PIN/VAT Certificate, Tax Compliance Certificate, Partnership Deed for Partnership Business, Memorandum/Articles of Association and CR12 mandatory for Registered Companies: For Construction Category - Letter/Certificate from the National Construction Authority, Energy Regulatory Commission or any other Authorized Public Technical Body (Mauki, 2014).

The infrastructural projects are often complex in nature, require high level of expertise and large financial resources requirements (Boraya, 2013). This has the impact of limiting the scope of activities that the youth, women and people with disabilities can undertake within the infrastructural project procurement activities. A majority of the youth, women and persons with disability enterprises fall under the small and medium enterprises with little expertise on highly technical projects (Mungai, 2014). These enterprises may also have challenges accessing the required financial resources from commercial banks due to lack of suitable collaterals. Due to the skills challenges and the huge financial resources required, the contractual capacity of the enterprises owned by the youth, women and persons with disability are seriously undermined (Telewa, 2014). However, by law at least $30 \%$ of the firms must be given to the youth, women and persons with disability hence KeRRA as an organization must allocate $30 \%$ of the procurement to the special groups. 


\section{Technical Capacity and Procurement Performance}

Suppliers' need competent technical ability to provide high quality product or service, ensure future improvements in performance and promote successful development efforts. Especially, this is very important when the firm's strategy included development of a new product or technology or access to proprietary technology. These technical criteria insist company to shift into the global market place. This factor has been measured on the basis of the importance of the following technical dimensions: compliance with quantity, compliance with due date, compliance with packaging standard, production planning systems of suppliers, maintenance activities of suppliers, plant layout and material (Harps, 2000).

According to Vinnova (2009) he suggested that this staff competence includes technical competence of the innovation as well as competence to manage the procurement process. This whole process is usually left to procurement professionals. Lawson and Squire (2006) did a research and established that purchasers with high skills and knowledge have a significant impact on financial performance and operational Performance in terms of quality improvement, design and reduction of lead times. This was similarly supported by studies done by Rothwell and Zegveld (1981), where they stated that whereas relatively little in-house competence is needed when procuring off-the shelf goods for the lowest possible price, greater competence of procurers is required to encourage suppliers to innovate.

\section{Community Support and Procurement Performance}

Any projects such as procurement must prudently management its stakeholders with a view of successfully achieve its objectives. The community forms a major stakeholder in any project that is undertaken in a given place. According to Shamala (2013), stakeholder management refers to any group or individual who can affect or be affected by the achievement of an organization's objectives or a project implementation. They can be internal or external to the organization and their complexity and range will depend on organization's size and activities (Muchiri, 2014). The environmental and social performance of organizations is increasingly under scrutiny from various stakeholders (Dobi, 2012). Greater economic and social knowledge is fueling stakeholders' demands for increased information, clarity, and involvement in business strategic changes (Wagaki, 2013).

Organizations can no longer choose if they want to engage with stakeholders or not; the only decision they need to take is when and how successfully to engage the various interested parties (Shamala, 2013). Stakeholder management is the process of founding, monitoring and maintaining constructive associations with stakeholders (Githika, 2013). In a business sense, it works over a strategy in project implementation. This strategy is bent using information gathered through various processes such as stakeholder mapping which enables managers to position stakeholders according to their level of influence or enrichment they provide to a change project (Mukhwana, 2013).

The development of meaningful relations with stakeholders adds value to an organization's operations and substantially towards successful project implementation (Mukhwana, 2013). It is regarded as a powerful tool that ensures key players are engaged in and contributing to the success of an initiative or project (Muchiri, 2014). It gives both the management and stakeholders a chance to discuss and concur upon expectations and most importantly agree on a common set of values and principles (Shamala, 2013). The lack of stakeholder involvement on the other hand often results in feelings of isolation and resentment.

The communities need to be considered within the procurement of services within their locality. The procurement of services during road construction is seen as the availing of economic opportunities to the local community in order to undertake manual services such as digging and guarding the construction equipment. The lack of availing of these opportunities to the local communities has the effect of alienating the community leading to the loss of critical good will among the local communities. This lack of good will may lead to the project sabotage leading to time wastage and cost escalation. The local community on the other hand can be engaged on a cheaper rate as there are little indirect costs such as housing associated with them as they come from the localities.

\section{Procurement Performance}

The procurement performance can be examined through diverse metrics including the time management, cost management, quality of work, value for money, adherence to the procurement law, and avoidance of litigations (Mwangi, 2014). The public procurement takes time through the aspects of advertisement and receipt of tenders, evaluations of these tenders and the capacity of the firms, awarding of tenders and contract signing, dealing with any arising issues, and finally the execution of the scope of the project (Telewa, 2014). The procuring entity should be able to undertake the procuring process in a timely manner in order to enable the undertaking of the scope of the project. Therefore, the lengthier the process in the undertaking of the procurement process the longer it takes for the procuring entity to undertake it functions (Ngotho, 2014). 
The budget/cost consideration is another procurement performance. The procuring entity incurs the costs in procurement such as the advertising costs and the assessment of the technical capacity of the procuring entities (Simbiri, 2010). In the event of any litigation due to arising matters, the procuring entity therefore spends more money in the legal process. The procuring entity may also incur cost in the enforcement of different contracts it has executed with the suppliers (Mwangi, 2014). The ability of the procuring entity to undertake the procurement process within the budget consideration ensures that little money is spent in the procurement process.

The integrity of the procurement process is also linked to the ability of the procuring entity to adhere to the procurement law and essentially avoidance of litigation from arising issues. The litigation essentially has the effect of stalling the procurement process and the eventual execution of the project as the legal process commences. Several strategies can be put in place to ensure adherence to the spirit and requirements of the public procurement (Mutua, 2010).

These may include sourcing, developing and maintaining good relationships with suppliers, developing suppliers, and adopting short to medium term contracts to take advantage of competing offers (Mauki, 2014). Other strategies include using standard inputs so that suppliers can be switched easily, centralized procurement to use purchase leverage, negotiation, and supplier segmentation among others (Kulundu, 2014). One of the major strategy used in public procurement include the use of the Kraljic supplier positioning model that group items dependent on the procurement difficulty and relative expenditure (Chirchir, 2013).

\section{Public Procurement Oversight Authority}

The Public Procurement Oversight Authority (PPOA) was created by the Public Procurement and Disposal Act of 2005. The other institutions that were created by the same act included the Public Procurement Advisory Board (PPAB), and the Public Procurement Administrative Review Board (PPARB) (Kulundu, 2014).The PPOA is mandated with the responsibility of ensuring that procurement procedures established under the Act are complied with; monitoring the procurement system and reporting on its overall functioning, initiating public procurement policy and assisting in the implementation and operation of the public procurement system (Chirchir, 2013). The other functions are preparing and distributing manuals and standard tender documents, providing advice and assistance to procuring entities, and develop, promote and support training and professional development of staff involved in procurement (Mutua, 2010).

\section{Objective of the Study}

The specific objectives of the study were:

(i). To examine the influence of contractual capacity on procurement performance at KeRRA, Nyamira County.

(ii). To analyze the impact of the Youth, Women and People with Disability involvement on procurement performance at KeRRA, Nyamira County.

(iii). To determine the influence of technical competency on procurement performance at KeRRA, Nyamira County.

(iv). To find out the influence of community support on procurement performance at KeRRA, Nyamira County.

\section{Research Hypotheses}

The study will guided by the following four hypotheses:

(i) $\mathbf{H}_{01}$ : There is no significant influence of contractual capacity of the supplier on procurement performance at KeRRA, Nyamira County.

(ii) $\mathbf{H}_{\mathbf{0 2}}$ : There is no significant impact of the Youth, Women and people with disability involvement on procurement performance at KeRRA, Nyamira County.

(iii) $\mathbf{H}_{\mathbf{0 3}}$ : There is no significant influence of technical competency on procurement performance at KeRRA, Nyamira County.

(iv) $\mathbf{H}_{04}$ : There is no significant influence of community support on procurement performance at KeRRA, Nyamira County.

\section{Methodology}

The research design was examined in the context of the research technique, research approach, and research methodology. The research design that was used for this study is the descriptive research. The study adopted the descriptive research design where selected staff of the county government of will provide information on behalf of their institution on the status of prequalification of suppliers in relation to procurement performance. The study was descriptive because it sought to document the current practices without modification of parameters. Kombo \& Tromp (2006) opine that descriptive research allows the researcher to study phenomena that do not allow for manipulation of variables. The survey technique on the other hand allows 
a researcher to obtain information from a section of the population carefully selected to provide inferences on an entire population.

The research approach the study undertook is the quantitative research in which the study was interested in numerical data in order to make statistical inferences on the study. There are diverse advantages associated with the quantitative study that informs its usage in this study. The quantitative research is often reliable, objective, use statistics to generalize the findings, and is able to test relationships. The primary research methodology will be used for the research. The primary research methodology enables the researcher to collect the data to be used in the research study and hence get first-hand information on the phenomenon under study. The study was carried out in the County Government of Nyamira County. The target population comprised 114 staff in procurement department in the County Government of Nyamira. The Yaro Yamane's simplified formula as provided by Njiru (2012)was used for the calculation of the sample size;

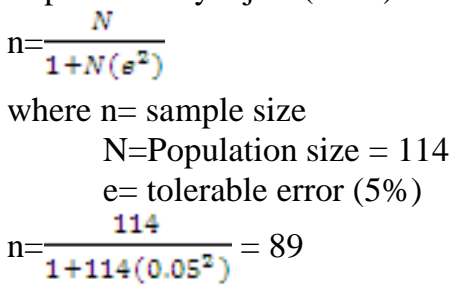

A sample size of 89 was thus be used for the study. The sample was selected using the stratified random sampling technique. The sampling strata will be developed based on the staff categories as indicated in table 1. This implies that the three strata were procurement managers, procurement officers and procurement clerks. The sampling within the strata was done using the simple random sampling in which each staff was assigned a random number from which staff were drawn repetitively to fill the required sample.

Table 1: Sampling Frame

\begin{tabular}{lcc}
\hline Staff Category & Population & Sample \\
\hline Procurement managers & 3 & 2 \\
Procurement officers & 39 & 30 \\
Procurement Clerks & 72 & 57 \\
Total & $\mathbf{1 1 4}$ & $\mathbf{8 9}$
\end{tabular}

Therefore, a total of 89 questionnaires were distributed to the respondents and of which 80 questionnaires were returned. Out of the returned questionnaires, a further 4 questionnaires were rejected due to being incompletely filled and therefore the analyzed questionnaires were 76 . Therefore, the response rate of the study is $85.4 \%$ of the distributed questionnaires were analyzed. This response rate is deemed sufficient by diverse scholars such as Kombo \& Tromp (2006) amongst others.

\section{Contractual Capacity and Procurement Performance}

\section{Findings and Discussions}

The contractual capacity and procurement performance was examined using the Table 2 below. The importance of the contractual capacity to the procurement performance was examined using five metrics; previous experience with similar projects being tendered for, possession of sufficient resources, possession of relevant expertise, previous experiences with projects of similar values, and possession of equipment to undertake the scope of procurement activities. A likert scale of Strongly Disagree (SD), Disagree (D), Uncertain (U), Agree (A) and Strongly Disagree (SA) was used.

In the context of previous experiences with projects of similar nature to the ones being tendered for, the results were $5.3 \%$ of the respondents strongly disagreed while $3.9 \%$ of the respondents disagreed. On the other hand, $23.7 \%$ of the respondents were uncertain, $36.8 \%$ of the respondents chose agree while $30.3 \%$ of the respondents strongly agreed. Previous experiences is considered critical in road construction due to the nature of the public infrastructure procurement involves relatively large amounts of budget considerations as well the complexity of the scope of work involved. This is especially so in terms of the road construction in which by nature is a complicated task involving heavy machinery, technical skills and the financial resources.

The ability of the firm tendering to undertake a given piece of work to have undertaken similar projects in the past is of critical importance to the performance of public procurement in infrastructural projects (Chirchir, 2013). This is because the past experiences indicate that the firms from which the services are being 
procured from have expertise to undertake the scope of work and have embraced the best practices that go with the work under scope. In the context of possession of sufficient resources, $14.5 \%$ of the respondents strongly disagreed, $39.5 \%$ of the respondents disagreed while $11.8 \%$ of the respondents were uncertain. On the other hand, $11.8 \%$ of the respondents agreed and $22.4 \%$ of the respondents strongly agreed.

The availability of the sufficient resources is critical in the procurement performance. This is because the tendering entities are able to embrace best practices. This ability to embrace the best practices over a period of time enhances the procurement performance as the firm saves on time and undertakes quality work. The aspect of time management is a critical performance measurement on the procurement performance within road infrastructure improvement and development. Firms lacking past experiences in undertaking a given scope of work are likely to underestimate the complexity of the work and the required time as well as resources requirements.

In relations to the possession of the relevant expertise, $11.8 \%$ of the respondents strongly disagreed, $38.2 \%$ of the respondents disagreed, and $13.2 \%$ of the respondents were uncertain. On the other hand, $25.0 \%$ of the respondents agreed in relation to the possession of relevant expertise while $11.8 \%$ of the respondents strongly agreed. The relevant expertise is critical in the procurement performance as it indicates that the firm has the capacity to undertake the work of the required scope and value. The value of work undertaken in the past is important to the contractual capacity of a given firm. The examination of the value of work undertaken in the past helps the procuring entity to determine on whether the firm had the enough capacity and expertise in terms of the number of employees, the skills set of the employees, and the required equipment (Mungai, 2014). If the value of the work undertaken is significantly lower than the current project then it may mean that the company may not have the capacity to undertake the current work.

Table 2; Frequency Distribution of Contractual Capacity in percentage

\begin{tabular}{|l|l|l|l|l|l|}
\hline STATEMENT & SA & A & U & D & SD \\
\hline $\begin{array}{l}\text { The majority of the suppliers tendering for } \\
\text { KeRRA procurements have undertaken } \\
\text { similar projects in the past }\end{array}$ & Freq(\%) & Freq(\%) & Freq(\%) & Freq(\%) & Freq(\%) \\
\hline $\begin{array}{l}\text { The majority of the suppliers tendering for } \\
\text { KeRRA procurements have sufficient } \\
\text { resources to undertake the work }\end{array}$ & $17(22.4)$ & $9(11.8)$ & $9(11.8)$ & $30(39.5)$ & $11(14.5)$ \\
\hline $\begin{array}{l}\text { The majority of the suppliers tendering for } \\
\text { KeRRA procurements always have the } \\
\text { relevant expertise to undertake the projects }\end{array}$ & $9(11.8)$ & $19(25.0)$ & $10(13.2)$ & $29(38.2)$ & $9(11.8)$ \\
\hline $\begin{array}{l}\text { The firms tendering for KeRRA } \\
\text { procurements have undertaken projects of } \\
\text { similar value of money in the past }\end{array}$ & $9(11.8)$ & $18(23.7)$ & $19(25.0)$ & $26(34.2)$ & $4(5.3)$ \\
\hline $\begin{array}{l}\text { The firms tendering for KeRRA have enough } \\
\text { equipment to undertake the scope of } \\
\text { procurement activities }\end{array}$ & $0(0.0)$ & $9(11.8)$ & $19(25.0)$ & $28(36.8)$ & $20(26.3)$ \\
\hline
\end{tabular}

On the other hand, the results for previous experiences with projects of similar values were $5.3 \%$ of the respondents strongly disagreeing, $34.2 \%$ of the respondents disagreeing, and $25.0 \%$ of the respondents were uncertain. On the other hand, $23.7 \%$ of the respondents agreed with the metric while a further $11.8 \%$ of the respondents strongly agreed. This is especially critical because firms without the required past experiences are likely to under estimate the financial resources required to undertake a given scope of work (Odongo, 2012). This impact greatly on the procurement performance when are not able to complete the work within the budget allocations. The firms are likely to request for more budget allocation to meet the raising costs or undertake a poor performance of the work with the required resources. Either way the procuring entity doesn't get the value for money.

Finally, the results for possession of equipment to undertake the scope of procurement activities were had $26.3 \%$ of the respondents strongly disagreeing, $36.8 \%$ of the respondents disagreeing, and $25.0 \%$ of the respondents were uncertain. On the other hand, $11.8 \%$ of the respondents agreed to possession of equipment to undertake scope of procurement activities. The possession of the right equipment is critical in procurement activities because road construction in which by nature is a complicated task involving heavy machinery, technical skills and the financial resources (Amin, 2012).

\section{YWP and Procurement Performance}

The influence of the YWP on procurement performance at KeRRA results were illustrated in Table 3. The importance of the Youth, Women and People with Disability involvement to the procurement performance was examined using five metrics; adherence to $30 \%$ allocation of procurement opportunities, sufficient youth, women and PAD groups tendering, possession of sufficient resources to undertake procurement activities, 
possession of sufficient expertise to tender for the procurement activities, and possession of sufficient experiences to undertake project scope. A likert scale of Strongly Disagree (SD), Disagree (D), Uncertain (U), Agree (A) and Strongly Disagree (SA) was used. In the context of adherence to $30 \%$ allocation of procurement opportunities the results were $3.9 \%$ of the respondents strongly disagreed, while $23.7 \%$ of the respondents disagreed.

On the other hand, $13.2 \%$ of the respondents were uncertain, $15.8 \%$ of the respondents agreed and $43.4 \%$ of the respondents strongly agreed. The adherence to the $30 \%$ allocation of procurement opportunities to youth, women and PAD is critical in the performance of the procurement activities. This is because there are several provisions within the Public Procurement and Disposal act 2013 that protects the rights of the youth, women and people with disabilities to participate in procurement (Muange, 2013).

The Public Procurement and Disposal Act of 2013 indicate that each public procuring entity must allocate at least $30 \%$ of its procurement within the financial year to the youth, women and people with disability (Mauki, 2014). Therefore, by law at least $30 \%$ of the firms must be given to the youth, women and persons with disability hence KeRRA as an organization must allocate $30 \%$ of the procurement to the special groups.

In the context of sufficient youth, women and PAD groups tendering, the results were $13.2 \%$ of the respondents strongly disagreeing, $25.0 \%$ of the respondents' disagreed, and $15.8 \%$ of the respondents were uncertain. On the other hand, $11.8 \%$ of the respondents agreed to the metric while $34.2 \%$ of the respondents strongly agreed. In order to ensure that the Youth, Women and PAD fully participate in procurement activities, any legal impediments to their participation were removed. In this context, the Public Procurement and Disposal Act of 2013 also limited the right of equality and freedom within the meaning of this act in order to remove any legal impediments on application of $30 \%$ special allocation to youth and women.

This was undertaken with a view of facilitating the affirmative action to ensure the youth access employment and have opportunities to participate in economic spheres of life as contemplated by Article 55 of the Constitution and second, for protection or advancement of the youth in accordance with Article 227 of the Constitution who have previously been disadvantaged by unfair competition and discrimination in the procurement process (Ngotho, 2014). In the context of the youth and women enterprises have sufficient resources to tender for procurement opportunities from KeRRA the results were $10.5 \%$ of the respondents strongly disagreed, $27.6 \%$ of the respondents disagreed, while $25.0 \%$ of the respondents were uncertain. On the other hand, $25.0 \%$ of the respondents agreed that youth and women enterprises have sufficient resources to tender for procurement opportunities from KeRRA while $11.8 \%$ of the respondents strongly agreed. The ability to have sufficient resources amongst the youth is often hampered by the fact that these groups have limited access to funds from commercial banks and other financiers. However, the possession of the right equipment is critical in procurement activities because road construction in which by nature is a complicated task involving heavy machinery, technical skills and the financial resources.

Table 3; Frequency Distribution of YWP Involvement in Percentage

\begin{tabular}{|l|l|l|l|l|l|}
\hline STATEMENT SA & A & U & D & SD \\
\hline $\begin{array}{l}\text { The 30\% allocation of procurement } \\
\text { opportunities allocation to women and } \\
\text { youth is always adhered to }\end{array}$ & Freq(\%) & Freq(\%) & Freq(\%) & Freq(\%) & Freq(\%) \\
\hline $\begin{array}{l}\text { There is sufficient number of youth, and } \\
\text { women enterprises tendering for } \\
\text { procurement opportunities from KeRRA }\end{array}$ & $26(34.2)$ & $12(15.8)$ & $10(13.2)$ & $18(23.7)$ & $3(3.9)$ \\
\hline $\begin{array}{l}\text { The youth and women enterprises have } \\
\text { sufficient resources to tender for } \\
\text { procurement opportunities from KeRRA }\end{array}$ & $9(11.8)$ & $19(25.0)$ & $19(25.0)$ & $21(27.6)$ & $8(10.5)$ \\
\hline $\begin{array}{l}\text { The youth and women enterprises have } \\
\text { enough expertise to tender for procurement } \\
\text { opportunities from KeRRA }\end{array}$ & & & $12(15.8)$ & $19(25.0)$ & $10(13.2)$ \\
\hline $\begin{array}{l}\text { The youth and women enterprises have } \\
\text { enough experiences to undertake the project } \\
\text { scope of procurement activities at KeRRA }\end{array}$ & $16(25.0)$ & $9(11.8)$ & $9(11.8)$ & $19(25.0)$ & $20(26.3)$ \\
\hline
\end{tabular}

In relations to the youth and women enterprises have enough expertise to tender for procurement opportunities from KeRRA the results were $26.3 \%$ of the respondents strongly disagreeing, $25.0 \%$ of the respondents disagreeing, while $11.8 \%$ of the respondents were uncertain. On the other hand, the youth and women enterprises have enough expertise to tender for procurement opportunities from KeRRA had $23.7 \%$ of the respondents agreeing and $13.2 \%$ of the respondents strongly agreeing.

The infrastructural projects are often complex in nature, require high level of expertise and large financial resources requirements (Boraya, 2013). This has the impact of limiting the scope of activities that the youth, women and people with disabilities can undertake within the infrastructural project procurement 
activities. A majority of the youth, women and persons with disability enterprises fall under the small and medium enterprises with little expertise on highly technical projects (Mungai, 2014). These enterprises may also have challenges accessing the required financial resources from commercial banks due to lack of suitable collaterals. Due to the skills challenges and the huge financial resources required, the contractual capacity of the enterprises owned by the youth, women and persons with disability are seriously undermined (Telewa, 2014).

Finally, in relations to possession of sufficient experiences to undertake project scope the results were $26.3 \%$ of the respondents strongly disagreeing, $25.0 \%$ of the respondents disagreeing while $11.8 \%$ of the respondents were uncertain. On the other hand, $11.8 \%$ of the respondents agreed that YWP had sufficient experiences to undertake project scope while $25.0 \%$ of the respondents strongly agreed to the same. The youth, women and PAD groups are often in the Small and Medium Enterprises who may not have undertaken a wide range of procurement activities at KeRRA. This is due to nature, scope and financial resources required to undertake the procurement activities.

Technical Competency and Procurement Performance

The results for the technical competency and procurement performance were illustrated in the Table 4

Table 4; Frequency Distribution of Technical Competency in Percentage

\begin{tabular}{|c|c|c|c|c|c|}
\hline STATEMENT & SA & $\mathbf{A}$ & $\mathbf{U}$ & D & SD \\
\hline & Freq(\%) & Freq(\%) & Freq(\%) & Freq(\%) & Freq(\%) \\
\hline $\begin{array}{l}\text { The education qualifications of the tendering } \\
\text { parties has an impact on procurement } \\
\text { performance at KeRRA }\end{array}$ & $25(32.9)$ & $17(22.4)$ & $20(26.3)$ & $6(7.9)$ & $8(10.5)$ \\
\hline $\begin{array}{l}\text { The professional qualifications of the } \\
\text { tendering parties has an impact on } \\
\text { procurement performance at KeRRA }\end{array}$ & $17(22.4)$ & $19(25.0)$ & $26(34.2)$ & $9(11.8)$ & $5(6.6)$ \\
\hline $\begin{array}{l}\text { The membership to professional bodies of the } \\
\text { tendering parties has an impact on } \\
\text { procurement performance at KeRRA }\end{array}$ & $4(5.3)$ & $9(11.8)$ & $31(40.8)$ & $18(23.7)$ & $14(18.4)$ \\
\hline $\begin{array}{l}\text { The ability to evaluate technical capacity of } \\
\text { the suppliers has an impact on procurement } \\
\text { performance at KeRRA }\end{array}$ & $28(36.8)$ & $29(38.2)$ & $10(13.2)$ & $6(7.9)$ & $3(3.9)$ \\
\hline $\begin{array}{l}\text { The legal expertise of the tendering parties has } \\
\text { an impact on procurement performance at } \\
\text { KeRRA }\end{array}$ & $18(23.7)$ & $21(27.6)$ & $13(17.1)$ & $18(23.7)$ & $6(7.9)$ \\
\hline
\end{tabular}

The importance of the technical capacity involvement to the procurement performance was examined using five metrics; education background of tendering parties, professional qualifications of tendering parties, membership to professional bodies, evaluation of technical capacity, and legal expertise of tendering parties. A likert scale of Strongly Disagree (SD), Disagree (D), Uncertain (U), Agree (A) and Strongly Disagree (SA) was used. In the context of the education qualifications of the tendering parties having an impact on procurement performance at KeRRA, the results were $10.5 \%$ of the respondents strongly disagreeing, $7.9 \%$ of the respondents disagreeing, while $26.3 \%$ of the respondents were uncertain.

On the other hand, $22.4 \%$ of the respondents agreed that education qualifications of the tendering parties had an impact on procurement performance at KeRRA while $32.9 \%$ of the respondents strongly agreed. The procurement process is a long one requiring the filling of a wide range of documentations. In this context, the ability of the prospective suppliers having sufficient education qualifications is thus important to be able to fill the required documentation.

In the context of professional qualifications of tendering parties importance to procurement performance the results were $6.6 \%$ of the respondents strongly disagreed, $11.8 \%$ of the respondents disagreed, $34.2 \%$ of the respondents were uncertain, $25.0 \%$ of the respondents agreed and $22.4 \%$ of the respondents strongly agreed. In the context of membership to professional bodies the results were $18.4 \%$ of the respondents strongly disagreeing, $23.7 \%$ of the respondents disagreed while $40.8 \%$ of the respondents were uncertain. On the other hand, $11.8 \%$ of the respondents agreed while $5.3 \%$ of the respondents strongly agreed that membership to professional bodies had an impact on the procurement performance.

The activities at KeRRA are often technical in nature requiring high skills levels in dynamic aspects of road construction and related aspects. The ability to have the right professional qualifications as well as membership to professional bodies demonstrate the possession of the right technical know how to handle the procurement roles. The results for the ability to evaluate technical capacity of the suppliers has an impact on procurement performance at KeRRA were $3.9 \%$ of the respondents strongly disagreeing, $7.9 \%$ of the respondents disagreeing while $13.2 \%$ of the respondents were uncertain.

On the other hand, $38.2 \%$ of the respondents agreed that evaluation of technical capacity of the suppliers had an impact on procurement performance at KeRRA while a further $36.8 \%$ of the respondents 
strongly agreed. Suppliers' need competent technical ability to provide high quality product or service, ensure future improvements in performance and promote successful development efforts. Especially, this is very important when the firm's strategy included development of a new product or technology or access to proprietary technology.

These technical criteria insist company to shift into the global market place. This factor has been measured on the basis of the importance of the following technical dimensions: compliance with quantity, compliance with due date, compliance with packaging standard, production planning systems of suppliers, maintenance activities of suppliers, plant layout and material (Harps, 2000).

Finally, in relations to the legal expertise the results were $7.9 \%$ of the respondents strongly disagreeing, $23.7 \%$ of the respondents disagreeing while $17.1 \%$ of the respondents were uncertain. On the other hand, $27.6 \%$ of the respondents agreed that legal expertise amongst tendering parties had an influence on the procurement performance at KeRRA while $23.7 \%$ of the respondents strongly agreed. The procurement opportunities at KeRRA are often complex and involving a vast amount of money in which breach of the terms have serious legal consequences. In this context, the legal expertise is of essence.

\section{Community Support and Procurement Performance}

The community support effect on the procurement performance was illustrated in the Table 5. The importance of community support to the procurement performance was examined using five metrics; engagement of local suppliers, local community goodwill, local community involvement to procurement function, local community giving value for procurement functions, and procurement from local community saving on time. A likert scale of Strongly Disagree (SD), Disagree (D), Uncertain (U), Agree (A) and Strongly Disagree (SA) was used. In the context of engagement of local suppliers the results were $11.8 \%$ of the respondents strongly disagreed, $6.6 \%$ of the respondents disagreed while $32.9 \%$ of the respondents were uncertain. On the other hand, $23.7 \%$ of the respondents agreed that engagement of local suppliers had an effect on the procurement performance at KeRRA while $25.0 \%$ of the respondents strongly agree. The engagement of the local suppliers is important to the performance of the procurement activities. The local suppliers are members of the local community whose goodwill is critical to the success of the procurement function. This is because the local suppliers are able to create economic opportunities for the population hence generating goodwill for the projects.

The results for the local community goodwill having an impact on the procurement performance at KeRRA were $11.8 \%$ of the respondents' strongly disagreeing, $38.2 \%$ of the respondents were uncertain, $13.2 \%$ choose agree while $36.8 \%$ of the respondents strongly agreed. This is important because the development of meaningful relations with stakeholders adds value to an organization's operations and substantially towards successful project implementation (Mukhwana, 2013). It is regarded as a powerful tool that ensures key players are engaged in and contributing to the success of an initiative or project (Muchiri, 2014). It gives both the management and stakeholders a chance to discuss and concur upon expectations and most importantly agree on a common set of values and principles (Shamala, 2013). The lack of stakeholder involvement on the other hand often results in feelings of isolation and resentment.

In relations to local community involvement to procurement function, $7.9 \%$ of the respondents strongly disagreed, $5.3 \%$ of the respondents disagreed, while $25.0 \%$ (U) of the respondents were uncertain. On the other hand, $25.0 \%$ of the respondents agreed that local community involvement had an impact on procurement function while $36.8 \%$ of the respondents strongly agreed. Local community involvement to procurement functions is critical because any projects such as procurement must prudently management its stakeholders with a view of successfully achieve its objectives. The community forms a major stakeholder in any project that is undertaken in a given place. According to Shamala (2013), stakeholder management refers to any group or individual who can affect or be affected by the achievement of an organization's objectives or a project implementation.

Table 5; Frequency Distribution for Community Support in Percentages

\begin{tabular}{|l|l|l|l|l|l|}
\hline STATEMENT & SA & A & U & D & SD \\
\hline & Freq (\%) & Freq (\%) & Freq (\%) & Freq (\%) & Freq (\%) \\
\hline $\begin{array}{l}\text { The engagement of the local suppliers has an } \\
\text { impact on the procurement performance at } \\
\text { KeRRA }\end{array}$ & $19(25.0)$ & $18(23.7)$ & $25(32.9)$ & $5(6.6)$ & $9(11.8)$ \\
\hline $\begin{array}{l}\text { The local community goodwill has an impact } \\
\text { on the procurement performance at KeRRA }\end{array}$ & $28(36.8)$ & $10(13.2)$ & $29(38.2)$ & $9(11.8)$ & $0(0.0)$ \\
\hline $\begin{array}{l}\text { The local community involvement in the } \\
\text { procurement function has an impact on the } \\
\text { procurement performance at KeRRA }\end{array}$ & $28(36.8)$ & $19(25.0)$ & $19(25.0)$ & $4(5.3)$ & $6(7.9)$ \\
\hline $\begin{array}{l}\text { The local community services give value for } \\
\text { the procurement functions at KeRRA }\end{array}$ & $9(11.8)$ & $48(63.2)$ & $9(11.8)$ & $10(13.2)$ & $0(0.0)$ \\
\hline The procurement of services from the local & $20(36.8)$ & $20(26.3)$ & $9(11.8)$ & $10(13.2)$ & $9(11.8)$ \\
\hline
\end{tabular}




\begin{tabular}{|l|l|l|l|l|l|}
\hline $\begin{array}{l}\text { community saves on time from procurement } \\
\text { functions at KeRRA }\end{array}$ & & & & \\
\hline $\begin{array}{l}\text { The interference from the local political class } \\
\text { has an influence on the procurement } \\
\text { functions at KeRRA }\end{array}$ & $36(47.4)$ & $18(23.7)$ & $9(11.8)$ & $5(6.6)$ & $8(10.5)$ \\
\hline
\end{tabular}

The results for the local community services give value for the procurement functions at KeRRA were $13.2 \%$ of the respondents disagreeing, $11.8 \%$ of the respondents were uncertain, $63.2 \%$ of the respondents agreed while $11.8 \%$ of the respondents strongly agreed. The communities need to be considered within the procurement of services within their locality. The procurement of services during road construction is seen as the availing of economic opportunities to the local community in order to undertake manual services such as digging and guarding the construction equipment. The lack of availing of these opportunities to the local communities has the effect of alienating the community leading to the loss of critical good will among the local communities. This lack of good will may lead to the project sabotage leading to time wastage and cost escalation. The local community on the other hand can be engaged on a cheaper rate as there are little indirect costs such as housing associated with them as they come from the localities

In relations to the procurement from local community saving on time the results were $11.8 \%$ of the respondents strongly disagreeing, $13.2 \%$ of the respondents disagreeing, while $11.8 \%$ of the respondents were uncertain. On the other hand $26.3 \%$ of the respondents agreed that procurement from the local community saved on time while a further $36.8 \%$ of the respondents strongly agreed on the same. The local community helps to save time because the procurement of services such as manual labour is cheaper and easier from local community. In the context of the interference from local political class, the results were $10.5 \%$ of the respondents strongly disagreeing, $6.6 \%$ of the respondents disagreeing, while $11.8 \%$ of the respondents were uncertain.

The local community plays a critical role in the procurement performance at KeRRA. This is because the local community is a critical stakeholder in the rural roads construction at Nyamira County. These roads are likely to interfere with people's land and businesses within the passage of the rural roads. The local community goodwill is therefore critical in this context.

\section{Procurement Performance}

The results for the procurement performance were illustrated in Table 6.

Table 6; Frequency Distribution for Procurement Performance in Percentages

\begin{tabular}{|l|l|l|l|l|l|}
\hline STATEMENT & SA & A & U & D & SD \\
\hline $\begin{array}{l}\text { The procurement functions at } \\
\text { KeRRA are undertaken within } \\
\text { adequate timelines }\end{array}$ & Freq (\%) & Freq (\%) & Freq (\%) & Freq (\%) & Freq (\%) \\
\hline $\begin{array}{l}\text { The procurement functions at } \\
\text { KeRRA enables the } \\
\text { government and taxpayer to get } \\
\text { value for money }\end{array}$ & $26(34.2)$ & $5(6.6)$ & $10(13.2)$ & $13(17.1)$ \\
\hline $\begin{array}{l}\text { The procurement functions at } \\
\text { KeRRA always adhere to the } \\
\text { public procurement laws }\end{array}$ & $20(26.3)$ & $28(36.8)$ & $6(7.9)$ & $14(18.4)$ & $8(10.5)$ \\
\hline $\begin{array}{l}\text { The procurement functions at } \\
\text { KeRRA always enables it to } \\
\text { get quality goods and services }\end{array}$ & $27(35.5)$ & $33(43.4)$ & $0(0.0)$ & $10(13.2)$ & $6(7.9)$ \\
\hline
\end{tabular}

The procurement performance was examined using four metrics; procurement functions undertaken within adequate timelines, achievement of value for money in procurement, adherence to procurement laws, and acquisition of quality goods and services. A likert scale of Strongly Disagree (SD), Disagree (D), Uncertain (U), Agree (A) and Strongly Disagree (SA) was used.

On the other hand, $23.7 \%$ of the respondents agreed that interference from local political class had an influence on the procurement performance while $47.4 \%$ of the respondents strongly agreed on the same. The interference from the political class has the effect of altering the scope of the project, quality of the project and the project timelines due to vested interests. The results for procurement functions undertaken within adequate timelines were $17.1 \%$ of the respondents strongly disagreeing, $13.2 \%$ of the respondents disagreeing while $6.6 \%$ of the respondents were uncertain. On the other hand, $34.2 \%$ of the respondents agreed that procurement functions undertaken within adequate timelines while $28.9 \%$ of the respondents strongly agreed on the same. The results for achievement of value for money in procurement were $11.8 \%$ of the respondents strongly disagreeing, $9.2 \%$ of the respondents disagreed while $6.6 \%$ of the respondents were uncertain. 
On the other hand, $38.2 \%$ of the respondents disagreed while $34.2 \%$ of the respondents strongly disagreed. The budget/cost consideration is consideration in procurement performance. The procuring entity incurs the costs in procurement such as the advertising costs and the assessment of the technical capacity of the procuring entities (Simbiri, 2010). In the event of any litigation due to arising matters, the procuring entity therefore spends more money in the legal process. The procuring entity may also incur cost in the enforcement of different contracts it has executed with the suppliers (Mwangi, 2014). The ability of the procuring entity to undertake the procurement process within the budget consideration ensures that little money is spent in the procurement process.

The results for adherence to procurement laws were $10.5 \%$ of the respondents strongly disagreeing, $18.4 \%$ of the respondents disagreeing while $7.9 \%$ of the respondents were uncertain. On the other hand, $36.8 \%$ of the respondents agreed while $26.3 \%$ of the respondents strongly agreed in relations to the respondents. The integrity of the procurement process is also linked to the ability of the procuring entity to adhere to the procurement law and essentially avoidance of litigation from arising issues. The litigation essentially has the effect of stalling the procurement process and the eventual execution of the project as the legal process commences. Finally, the results for acquisition of quality goods and services were $7.9 \%$ of the respondents strongly disagreeing, $13.2 \%$ of the respondents disagreeing, $43.4 \%$ of the respondents agreeing, and $35.5 \%$ of the respondents strongly agreeing. The quality of goods implies that the citizens get values for money in the services provided.

\section{Hypotheses Testing}

The one way ANOVA test statistic was used for hypotheses testing of this study. The following steps were followed during the hypothesis testing. The composite variable of the procurement performance (dependent variable) was extracted using SPSS. The individual metrics of each independent variable were then regressed against the dependent variable. The $\mathrm{p}$ value of the ANOVA Table was then compared to the significance level $(\alpha)$ of 0.05 and thus informing on whether to reject or not to reject the null hypothesis. If the p-value was less than the significance level, the null hypothesis was rejected (if p-value $<\alpha$, reject the null). If p-value was greater than or equal to the significance level, the null hypothesis was not rejected.

$\boldsymbol{H}_{01}$ : There is no significant influence of contractual capacity of the supplier on procurement performance at KeRRA, Nyamira County.

Table 7; Contractual Capacity ANOVA ${ }^{\mathrm{a}}$

\begin{tabular}{|l|l|l|l|l|l|l|}
\hline Model & Sum of Squares & df & Mean Square & F & Sig. \\
\hline \multirow{4}{*}{1} & Regression & 34.922 & 5 & 6.984 & 10.345 & $.000^{\mathrm{b}}$ \\
\cline { 2 - 7 } & Residual & 47.258 & 70 & .675 & & \\
\cline { 2 - 7 } & Total & 82.180 & 75 & & & \\
\hline
\end{tabular}

Level of Significance; 0.05

The Table 7 shows that contractual capacity metrics significantly predict the dependent variable, F (5, $70)=10.345, \mathrm{p}<0.05$ (i.e., the regression model is a good fit of the data). The null hypothesis $H_{0 I}$ : That there is no significant influence of contractual capacity of the supplier on procurement performance at KeRRA, Nyamira County was rejected since $\mathrm{p}$ value was less than 0.05 .

$\boldsymbol{H}_{02}$ : There is no significant impact of the Youth, Women and people with disability involvement on procurement performance at KeRRA, Nyamira County.

Table 8; Youth, Women and People with Disabilities ANOVA

\begin{tabular}{|l|l|l|l|l|l|l|}
\hline Model & Sum of Squares & df & Mean Square & F & Sig. \\
\hline \multirow{5}{*}{1} & Regression & 22.063 & 5 & 4.413 & 5.138 & $.000^{\mathrm{b}}$ \\
\cline { 2 - 6 } & Residual & 60.117 & 70 & .859 & & \\
\cline { 2 - 6 } & Total & 82.180 & 75 & & \\
\hline
\end{tabular}

Level of Significance; 0.05

The Table 8 shows that YWP metrics significantly predict the dependent variable, $\mathrm{F}(5,70)=5.138, \mathrm{p}$ $<.005$ (i.e., the regression model is a good fit of the data). The null hypotheses $\mathrm{H}_{02}$ : There is no significant impact of the Youth, Women and people with disability involvement on procurement performance at KeRRA, Nyamira County was rejected at 0.05 level of significance. 
$\boldsymbol{H}_{03}:$ There is no significant influence of technical competency on procurement performance at KeRRA, Nyamira County.

Table 9 Technical Competency ANOVA

\begin{tabular}{|l|l|l|l|l|l|l|}
\hline Model & Sum of Squares & df & Mean Square & F & Sig. \\
\hline \multirow{4}{*}{1} & Regression & 22.272 & 5 & 4.454 & 5.205 & $.000^{\mathrm{b}}$ \\
\cline { 2 - 6 } & Residual & 59.908 & 70 & .856 & & \\
\cline { 2 - 6 } & Total & 82.180 & 75 & & & \\
\hline
\end{tabular}

Level of Significance; 0.05

The Table 9 shows that technical competency metrics significantly predict the dependent variable, $\mathrm{F}$ (5, $70)=5.205, \mathrm{p}<.005$ (i.e., the regression model is a good fit of the data). The null hypotheses $\mathrm{H}_{03}$ : There is no significant influence of technical competency on procurement performance at KeRRA, Nyamira County was rejected at 0.05 level of significance.

$\mathbf{H}_{\mathbf{0 4}}$ : There is no significant influence of community support on procurement performance at KeRRA, Nyamira County.

Table 10 Community Support ANOVA

\begin{tabular}{|l|l|l|l|l|l|l|}
\hline Model & Sum of Squares & df & Mean Square & F & Sig. \\
\hline \multirow{5}{*}{1} & Regression & 38.626 & 5 & 7.725 & 12.416 & $.000^{\mathrm{b}}$ \\
\cline { 2 - 7 } & Residual & 43.554 & 70 & .622 & & \\
\cline { 2 - 6 } & Total & 82.180 & 75 & & & \\
\hline \multicolumn{2}{|l|}{ a. Dependent Variable: Procurement Performance } \\
\hline
\end{tabular}

Level of Significance; 0.05

Table 10 shows that community support metrics significantly predict the dependent variable, $\mathrm{F}(5,70)$ $=12.416, \mathrm{p}<.005$ (i.e., the regression model is a good fit of the data). The null hypotheses $\mathrm{H}_{04}$ that there is no significant influence of community support on procurement performance at KeRRA, Nyamira County was rejected at 0.05 level of significance.

\section{Multiple Linear Regression}

Multiple linear regressions are used for the purposes of investigating the effect of the four independent variables on the dependent variable. The multiple correlation coefficient is used to measure the relationship between the independent variables and the dependent variable. In this context, the multiple correlation coefficient $(\mathrm{R})$ is positive indicating a positive correlation between the cumulative effect of the four independent variables on the dependent variable. The multiple correlation effect of 0.538 indicates a relatively strong positive relationship effect between the four independent variables (Community Support, Contractual Capacity, Technical Capacity, Youth and Women Involvement) and the dependent variable (procurement performance). On the other hand, the coefficient of determination (R Square) indicates the variance on the dependent variable attributed to the four independent variables. In this context, the coefficient of determination (R Square) of 0.290 indicates that the four independent variables contributed to $29.0 \%$ of the variance in dependent variable. This would indicate that there are other variables that attributed to $71 \%$ variance in the performance of the procurement performance.

Table 11; Model Summary

\begin{tabular}{|l|l|l|l|l|}
\hline Model & $\mathrm{R}$ & $\mathrm{R} 2$ & Adjusted R 2 & Std. Error of the Estimate \\
\hline 1 & $.538^{\mathrm{a}}$ & .290 & .250 & .90657 \\
\hline
\end{tabular}

To test on whether the regression model is a good fit for the data then the F-ratio examined in the ANOVA Table. Table 12 shows that the independent variables statistically significantly predict the dependent variable, $\mathrm{F}(4,71)=7.248, \mathrm{p}<.005$ (i.e., the regression model is a good fit of the data). There is therefore a significant relationship between Youth and Women Involvement, Community Support, Contractual Capacity, Technical Capacity, and procurement performance.

Table 12; ANOVA

\begin{tabular}{|l|l|l|l|l|l|l|}
\hline Model & Sum of Squares & df & Mean Square & F & Sig. \\
\hline \multirow{2}{*}{1} & Regression & 23.827 & 4 & 5.957 & 7.248 & $.000^{\mathrm{b}}$ \\
\cline { 2 - 8 } & Residual & 58.353 & 71 & .822 & & \\
\hline
\end{tabular}


Influence of Supplier Prequalification Criteria on Procurement Performance at Kenya Rural Roads....

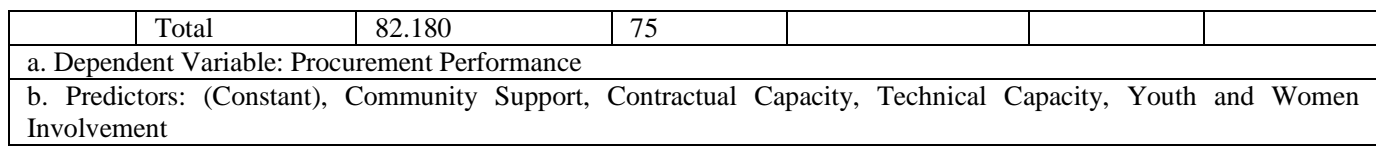

Table 13 shows the multiple regression coefficients. To indicate the effect of the variance of the dependent variable as a result of an individual independent variable with the other independent variables kept constant, then the unstandardized coefficients are used. The results indicates that three independent variables that is contractual capacity, Youth, women and persons with disabilities, and community support individually had positive variance on the procurement performance with other variables kept constant.

However, the technical capacity with other independent variables kept constant had a negative effect on procurement performance. This doesn't mean that the technical capacity is not important in procurement performance. The interpretation is that the technical capacity metrics used in the study on their own would not be sufficient to have a positive effect on the procurement performance. The technical capacity metrics that were used for the study included education qualifications of tendering parties, professional qualifications of tendering parties, membership to professional bodies, and legal expertise of tendering parties.

Regression Model

Procurement Performance $=3.289+0.164\left(x_{i 1}\right)+0.299\left(x_{i 2}\right)-0.747\left(x_{i 3}\right)+0.330(x i 4)$ where

$x_{i l}=$ Contractual capacity

$x_{i 2}=$ Youth and Women Involvement

$x_{i 3}=$ Technical competency

$x_{i 4}=$ Community support

The coefficient for the intercept is 3.289 implies that if the factors (Youth and Women Involvement, Community Support, Contractual Capacity, Technical Capacity) are equated to zero then the procurement performance will stand at 3.289. The beta coefficient of contractual capacity is 0.164 implying that a unit increase in contractual capacity will lead to an increase in procurement performance by a margin of 0.164 .

The beta coefficient of technical capacity is -0.747 implying that a unit increase in technical capacity leads to a decline in the procurement performance by a margin of 0.747 . Similarly, the beta coefficient of Youth, Women and People with Disabilities is 0.299 implying that a unit increase in Youth, Women and People with Disabilities leads to an increase in procurement performance by a margin of 0.299 . Finally, a unit increase in community support leads to an increase in procurement performance by a margin of 0.330 .

Table 13; Multiple Linear Regression Coefficients

\begin{tabular}{|c|c|c|c|c|c|c|}
\hline \multirow{2}{*}{\multicolumn{2}{|c|}{ Model }} & \multicolumn{2}{|c|}{ Unstandardized Coefficients } & \multirow{2}{*}{$\begin{array}{l}\text { Standardized Coefficients } \\
\text { Beta }\end{array}$} & \multirow[t]{2}{*}{$\mathbf{t}$} & \multirow[t]{2}{*}{ Sig. } \\
\hline & & B & Std. Error & & & \\
\hline \multirow[t]{5}{*}{1} & (Constant) & 3.289 & .588 & & 5.591 & .000 \\
\hline & Contractual Capacity & .164 & .261 & .142 & .628 & .532 \\
\hline & Technical Capacity & -.747 & .213 & -.537 & -3.506 & .001 \\
\hline & Youth Women Involvement & .299 & .215 & .318 & 1.388 & .170 \\
\hline & Community Support & .330 & .136 & .365 & 2.434 & .017 \\
\hline
\end{tabular}

\section{Recommendations}

The recommendations are based on the four independent variables. In the context of the contractual capacity, KeRRA should ensure that firms tendering the procurement activities have enough equipment to undertake the scope of the procurement activities. The emphasis on this aspect is informed by the fact that this metric had the lowest score amongst the contractual capacity scores. In the context of the Youth, Women and People with Disability involvement at KeRRA, the organization should hold seminars and conferences to ensure that the YWP are experienced to undertake the project scope of procurement activities. The emphasis on this aspect is informed by the fact that this metric had the lowest score amongst the YWP scores. In the context of the technical competency, the KeRRA should examine the relevancy of the professional membership in enhancing the procurement performance at the organization. The relevant membership to professional bodies should be procurement related. KeRRA should ensure that the engagement of the local community in procurement activities adds value to procurement performance through ensuring that the community is engaged in issues that are within their scope in terms of experience and expertise. 


\section{References}

[1]. Amin, A. (2012). Electronic Procurement and Organizational Performance Among Commercial State Corporations. Interdisciplinary Journal of Contemporary Research in Business, 3(4), 10-16.

[2]. Boraya, N. (2013). Collaborative Public Procurement and Performance Among State Corporations in Kenya. Journal of Business and Management, 1(1), 29-32.

[3]. Chirchir, N. (2013). The Implementation of the Public Procurement and Disposal ACT, 2005; A Case of Public Secondary Schools in Nairobui County, Kenya. International Review of Management and Business Research, 1(2), 37-42.

[4]. Dobi, B. (2012). Factors Influencing Adoption of Monitoring and Evaluation System for Project Management Among NGOs in Rarieda District, Siaya County, Kenya. Journal of Sustainable Development in Africa, 2(3), 25-30.

[5]. Fathi, J. (2013). Corporate governance and the level of financial disclosure by Tunisian firm. Journal of Business Studies Quarterly, 4(3), 95-111.

[6]. Githemo, M. (2012). The Effect of Agency Banking on Financial Performance of Small and Medium Sized Enterprises in Nairobi County. Journals in Business \& Management, 2(2), 35-40.

[7]. Githika, M. (2013). Influence of Project Management Practices on Implementation of HIV and Aids Projects: A Case of Civil Society Organization in Imenti North Subcounty, Meru County Kenya. Journal of Management and Business Studies, 2(3), 45-50.

[8]. Kariuki, E. (2013). Procurement Performance Measurement in Commercial Banks in Kenya. International Journal of Social Sciences and Entrepreneurship, 3(3), 14-19.

[9]. Kulundu, L. (2014). Challenges of Procurement Strategy Implementation among Road Agencies in Kenya. International Journal of Business, Humanities and Technology, 1(2), 12-21.

[10]. Makokha, P. (2013). The Effect of Privatization on Financial Performance of Firms Listed at the Nairobi Securities Exchange. Journal of Accounting and Finance.

[11]. Mauki, R. (2014). The Regions Perspective of the Factors Infleuncing the Implementation of Public Procurement and Disposal ACT in the Kenyan Judiciary. Journal of Management Research, 2(3), 19-24.

[12]. Mbae, L. (2014). Public Procurement Law and Procurement Performance of County Government in Kenya; Case of Machakos County Government. International Journal of Research in Management, Economics and Commerce, 2(2), 14-19.

[13]. Muange, E. (2013). Procurement Legislation and Performance of Constituency Fund Committees in Kenya. International Journal of Science and Research, 2(3), 19-22.

[14]. Muchiri, N. (2014). Influence of Community Participation in Project Management Processes on the Timely Completion of CDF projects in Kanyekini Ward-Kirinyaga County, Kenya. Journal of Management Research, 2(3), 15-17.

[15]. Mukhwana, A. (2013). Challenges facing Implementation of Telehealth projects in Kenya. International Journal of Business and Social Research, 2(3), 29-35.

[16]. Mungai, N. (2014). Factors Influencing Implementation of Public Procurement and Disposal Act, 2005 in Public Day Secondary Schools in Mukurwe-ini Sub County, Nyeri County, Kenya. International Journal of Science and Research, 2(3), 12-19.

[17]. Mutua, O. (2010). Public Procurement Practices: Policy Implications and Service Delivery in Selected Ministries Headquarters in Naiorbi County, Kenya. Interdisciplinary Journal of Contemporary Research in Business, 2(1), 17-22.

[18]. Mwangi, M. (2014). The Impact of Public Procurement Policy on Teaching and Learning in Selected Public Secondary Schools in Kahuro District, Murang'a County, Kenya. Interdisciplinary Journal of Contemporary Research in Business, 2(3), 25-36.

[19]. Ngotho, M. (2014). Public Procurement Practices and Development of MSEs in Kenya; Case of Roads Sector. International Multidisciplinary Journal, 2(2), 26-29.

[20]. Ngunyi, I. W. (2014). Procurement Practices and the Performance of Parastatals in Kenya . International Journal of Humanities and Social Sciences, 1(2), 49-54.

[21]. Njiru, C. (2012). Strategic Responses to Changes in the External Environment by Universities in Kenya. International Journal of Arts and Commerce, 3(4), 30-35.

[22]. Odongo, G. (2012). Adoption and Risks of Electronic Procurement among Automated Teller Machine Solutions Providers in Kenya. Journal of Modern Accounting and Auditing, 3(4), 4-10.

[23]. Simbiri, A. (2010). Investigation of the Barriers to Small and Medium Enterprises Accessing Public Procurement Market. International Journal of Humanities and Social Sciences, 1(1), 17-20.

[24]. Telewa, S. (2014). Sustainable Procurement Practices in the Public Water Sector Institutions in Kenya. Journal of Management and Business Studies, 2(3), 19-25.

[25]. Wagaki, S. (2013). Strategic Management Practices and Challenges of Kenyan Projects Assisted by Compassion International in Limuru Region. Journal of Management Research, 2(2), 25-27. 